\title{
The smallest eating the largest: the oldest mammalian feeding traces on dinosaur bone from the Late Jurassic of the Junggar Basin (northwestern China)
}

\author{
Felix J. Augustin ${ }^{1}$ (D) - Andreas T. Matzke ${ }^{1} \cdot$ Michael W. Maisch ${ }^{2} \cdot$ Juliane K. Hinz $^{1} \cdot$ Hans-Ulrich Pfretzschner ${ }^{1}$
}

Received: 18 March 2020 / Revised: 9 July 2020 / Accepted: 13 July 2020 / Published online: 19 July 2020

(C) The Author(s) 2020

\begin{abstract}
Reconstructing trophic interactions in ancient ecosystems is an important and fascinating branch of palaeontological research. Here we describe small bioerosional traces that are preserved on sauropod bone from the early Late Jurassic Qigu Formation (Oxfordian) of Liuhuanggou gorge in the southern Junggar Basin (Xinjiang Province, northwestern China). The most likely producers of these traces are tiny Mesozoic mammals as evinced by the small size of the traces as well as by their paired and opposed arrangement. The feeding traces are only superficially preserved on the bone surface and most likely were inflicted unintentionally during feeding. The occurrence of the bite marks along small ridges and the "gnawed" appearance of the bone surface points to selective feeding on the remaining soft tissues of the dinosaur carcass. The traces represent the oldest direct evidence for mammalian feeding behaviour in the fossil record. Additionally, these traces expand the known range of the early mammalian feeding repertoire significantly and shed light on the palaeobiology and palaeoecology of early mammals, a field that has remained evasive for a long time.
\end{abstract}

Keywords Bite marks $\cdot$ Early mammals $\cdot$ Palaeobiology $\cdot$ Dinosaurs $\cdot$ Late Jurassic $\cdot$ Junggar Basin

\section{Introduction}

For more than 160 million years, mammals lived in the shadow of the dinosaurs, remaining small and elusive with an average adult body size close to $100 \mathrm{~g}$ (Luo 2007; Lee and Beck 2015). Nonetheless, recent discoveries demonstrate that Mesozoic mammals were ecologically diverse and occupied various ecological niches. They ranged from ground-dwelling generalists to

Communicated by: Aurora Grandal d'Anglade

Institutional abbreviation SGP - Sino-German Project collection, currently housed at the University of Tübingen, Germany. The collection remains the property of the People's Republic of China and will be transferred to a Chinese public collection after the scientific studies are completed. The final repository will be announced in an internationally accessible journal.

Felix J. Augustin

felix.augustin@uni-tuebingen.de

1 Institut für Geowissenschaften, Eberhard Karls Universität Tübingen, Hölderlinstraße 12, 72074 Tübingen, Germany

2 Albstadt, Germany specialists with semi-aquatic, fossorial, arboreal and even gliding habits (Luo 2007). This ecological diversity suggests an equally varied diet, probably encompassing herbivory, insectivory, carnivory and omnivory (Luo 2007). The reconstruction of the diet and feeding behaviour of Mesozoic mammals is, however, largely based on circumstantial evidence such as tooth morphology. Direct evidence for feeding behaviour is scarce and so far limited to a stomach content from the Early Cretaceous (Hu et al. 2005), and four instances of feeding traces on bones from the Late Cretaceous (Longrich and Ryan 2010; de Valais et al. 2012; Gianechini and de Valais 2015; Augustin et al. 2019).

Here we describe bioerosional traces preserved on dinosaur bone from the early Late Jurassic Qigu Formation (Oxfordian, approximately $160 \mathrm{Ma}$ ) of the southern Junggar Basin, northwestern China, and argue that they represent the oldest direct evidence of mammalian feeding behaviour. This predates the hitherto oldest feeding traces ascribed to mammals from the Late Cretaceous (Longrich and Ryan 2010; de Valais et al. 2012; Gianechini and de Valais 2015; Augustin et al. 2019), by more than 60 million years. Thus, our findings significantly expand our understanding of the ecology and behaviour of early mammals. 


\section{Material and methods}

\section{Geological setting}

The bioerosional traces were discovered on a bone fragment of a sauropod dinosaur at the northern flank of Liuhuanggou gorge ( $\left.43^{\circ} 42^{\prime} 56^{\prime \prime} \mathrm{N}, 87^{\circ} 10^{\prime} 21^{\prime \prime} \mathrm{E}\right)$ in the southern Junggar Basin (Xinjiang Province, northwestern China), approximately $40 \mathrm{~km}$ southwest of Urumqi (Fig. 1a, b). The locality was discovered during the Sino-German-Project in 2000, a joint expedition by the University of Tübingen, the Nanjing Institute for Geology and Palaeontology and the Geological Survey No. 1 of Xinjiang. The trace-bearing bone was associated with other fragmentary bones of a large-sized mamenchisaurid sauropod dinosaur in a bone-bed horizon in the lower part of the Qigu Formation, approximately $50 \mathrm{~m}$ above the boundary with the underlying Toutunhe Formation (sensu Ashraf et al. 2010). The sauropod dinosaur total length was estimated to be more than $20 \mathrm{~m}$. Theropod teeth were found interspersed between the sauropod remains and belong to a large-sized carnosaur and a smaller theropod of unknown affinities (Maisch and Matzke 2003).

The Qigu Formation is early Late Jurassic in age (Eberth et al. 2001; Li et al. 2014; Fang et al. 2015, 2016) and has a thickness of $680 \mathrm{~m}$ at Liuhuanggou gorge (Ashraf et al. 2010). It consists of massive reddish mudstones and siltstones interbedded with fine-grained sandstone horizons (Fig. 1c). The sediments of the Qigu Formation were probably deposited on a low-gradient alluvial plain, composed of extensive floodplain areas, adjacent to braided river systems and slow- flowing meandering rivers (Eberth et al. 2001; Li et al. 2014; Fang et al. 2016). Environmental conditions during the time of deposition have been interpreted as arid and highly seasonal (Ashraf et al. 2010; Li et al. 2014; Fang et al. 2015, 2016). The diverse vertebrate fauna of the Qigu Formation thus far comprises hybodont sharks, actinopterygian fishes, temnospondyl amphibians, mammals, xinjiangchelyid turtles, squamates and choristoderes, crocodylomorphs, pterosaurs, as well as sauropods, small and large theropods, stegosaurs and ankylosaurs among dinosaurs (Maisch et al. 2003, 2004a, b, 2005; Maisch and Matzke 2005, 2014, 2017; Wings et al. 2007; Schellhorn et al. 2009; Martin et al. 2010; Richter et al. 2010; Augustin et al. in press). The mammal assemblage is particularly rich and comprises five different taxa: the haramiyid Sineleutherus; two docodonts, Tegotherium and Dsungarodon; the stem zatherian Nanolestes; and an indeterminate amphilestid triconodont (Pfretzschner et al. 2005; Maisch et al. 2005; Martin et al. 2010). All of these mammals were found in a microvertebrate-bearing bone-bed at Liuhuanggou gorge close $(300 \mathrm{~m})$ to the dinosaur bone-bed site. Stratigraphically, the mammal site occurred only slightly higher $(70 \mathrm{~m})$ in the section, indicating that the dinosaur and the mammals lived more or less coeval in the same ecosystem.

\section{Description of sample}

The bioerosional traces are preserved on a fragmentary cervical rib of an indeterminate mamenchisaurid sauropod dinosaur (SGP 2000/16) (Fig. 2a). Although dozens of cervical rib fragments have been recovered from the dinosaur site at Liuhuanggou,
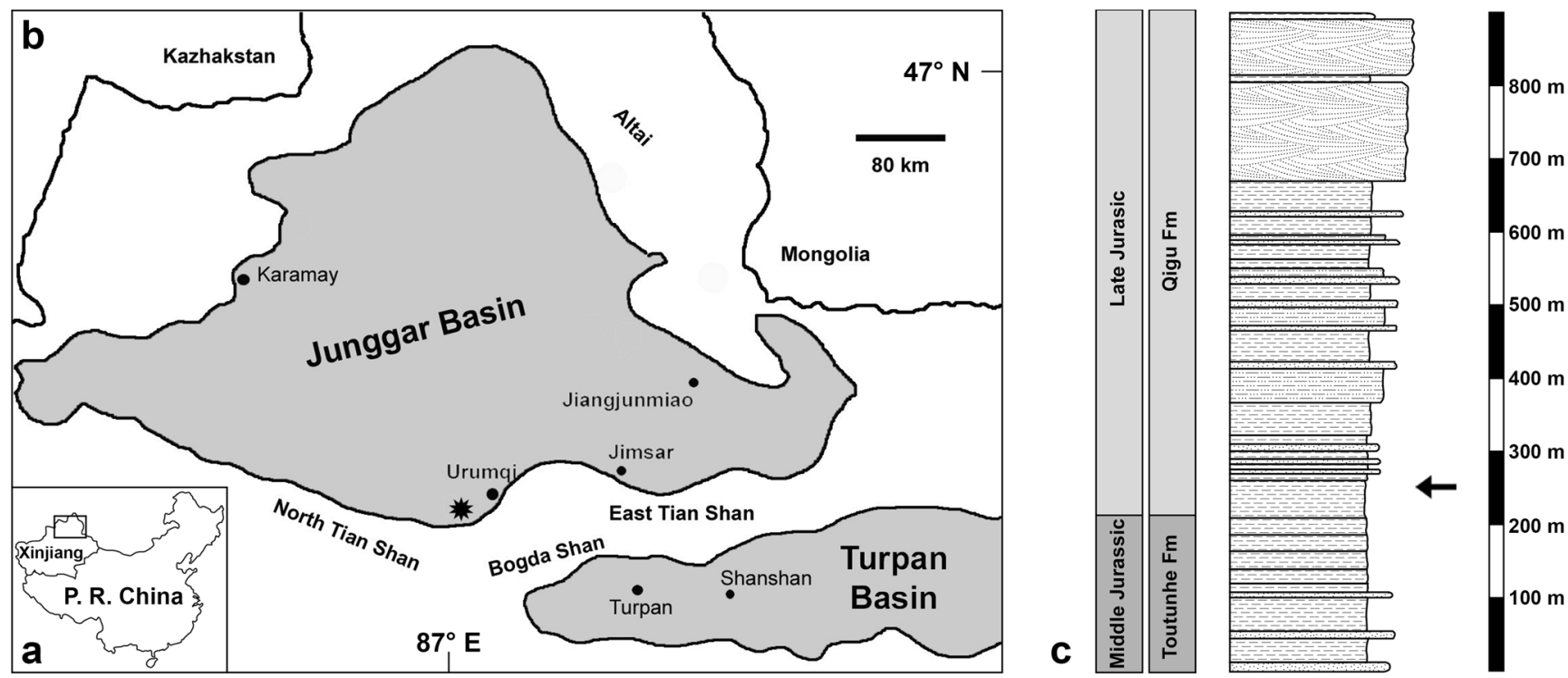

Fig. 1 Map and stratigraphy of Liuhuanggou gorge. (a) Inset shows the position of the Junggar Basin (rectangle) within Xinjiang Province in northwestern China. Modified from Augustin et al. (in press). (b) Geographic map of the Junggar Basin (Xinjiang Province, northwest China) and the position of Liuhuanggou gorge (asterisk). (c)
Stratigraphy and sedimentology of the Toutunhe and Qigu Formation at the northern flank of Liuhuanggou gorge. The arrow marks the position of the dinosaur bone-bed from which the bite marked bone was recovered. Modified from Ashraf et al. (2010) 
small bioerosional traces were only found on one bone fragment. Interestingly, the traces are limited to small ridges on the bone and do not occur on the more level or concave surfaces in between (Fig. 2b, c). They appear as elongated, shallow depressions that are restricted to the cortical bone and are principally arranged in parallel pairs. The traces are usually aligned opposite to each other, with one set of traces visible on one side of the ridge and the other set on the opposite side (Fig. 2b, c). The traces have a length of approximately $0.5-1.5 \mathrm{~mm}$ and a width of 30 $250 \mu \mathrm{m}$. For the measurement of the trace size, we used the methodology of Tong et al. (2008).

\section{Discussion}

Small and elongated traces on bones have been linked to the following causes: trampling by large vertebrates (e.g. Behrensmeyer et al. 1986; Olsen and Shipman 1988; Fiorillo 1991; Augustin et al. 2019), feeding by insects (e.g. Fejfar and Kaiser 2005; Britt et al. 2008; Pomi and Tonni 2011; Backwell et al. 2012; Gianechini and de Valais 2015; Augustin et al. 2019) and feeding by vertebrates (Longrich and Ryan 2010; Gianechini and de Valais 2015; Augustin et al. 2019). Below, we discuss all the possible trace-makers for the bioerosional traces described in the previous sections of this manuscript and conclude that they were most likely produced by early Mesozoic mammals.

Trampling by large vertebrates has often been inferred by the presence of small micro-striations on bone surfaces in fossil and sub-fossil settings. These micro-striations are much smaller, parallel and more uniform to one another (Behrensmeyer et al. 1986: Figs. 2-3; Olsen and Shipman 1988: Figs. 3-4; Fernández-Jalvo and Andrews 2016: Figs. A.84-86), and are therefore different from the traces described here.
Insect traces are widespread in the fossil record and range in morphology from cavities and tunnels to star-shaped pits (Augustin et al. 2019). Elongated grooves have also been ascribed to insects, particularly dermestid beetles (e.g. Britt et al. 2008) and termites (e.g. Fejfar and Kaiser 2005; Pomi and Tonni 2011; Backwell et al. 2012; Augustin et al. 2019). The wellpreserved traces from the Qigu Formation (Fig. 2b) differ from these insect feeding traces in having a teardrop shape, with one pointed and one blunt end. When several scratches occur as opposed parallel pairs, the blunt ends face each other (Fig. 2a). In these traces, the deepest part of the scratches is near the blunt end and not near the mid-length as it is the case in termite traces (Augustin et al. 2019: Fig. 7A-B). Additionally, termite feeding traces often comprise star-shaped pits and are usually superimposed on one another, resulting in heavily bioeroded surfaces lacking most of the compact bone layer (e.g. Fejfar and Kaiser 2005; Pomi and Tonni 2011; Backwell et al. 2012; Augustin et al. 2019). Therefore, we conclude that insects are not responsible for the traces.

Vertebrate feeding traces are frequently preserved on bones and usually come in the form of punctures, scores and grooves. The only vertebrates from the Qigu Formation that fall within the size range of the traces described above are mammals (Pfretzschner et al. 2005; Martin et al. 2010), as well as squamates and one possible choristoderan (Richter et al. 2010); however, the dentition pattern of squamates and choristoderans is incompatible with the arrangement of the bite marks described here. Both possess a homodont dentition with closely packed and irregularly spaced teeth in the upper and lower jaw, and therefore, they cannot be the producer of these traces.

Mammals are the only vertebrates that possess two sets of procumbent, paired incisors in the upper and lower jaw and can produce bite marks of the kind described above. The
Fig. 2 Cervical rib of a mamenchisaurid sauropod (SGP 2000/16) from the lower Qigu Formation (Oxfordian, Late Jurassic) of Liuhuanggou gorge, northwestern China. (a) Overview photograph of the specimen (SGP 2000/16) displaying bioerosional traces. (b) Detail photograph of the bioerosional traces from a slightly different angle than in (a) for better visibility of the traces. (c) Detail photograph of the bioerosional traces from a slightly different angle than in (a) for better visibility of the traces
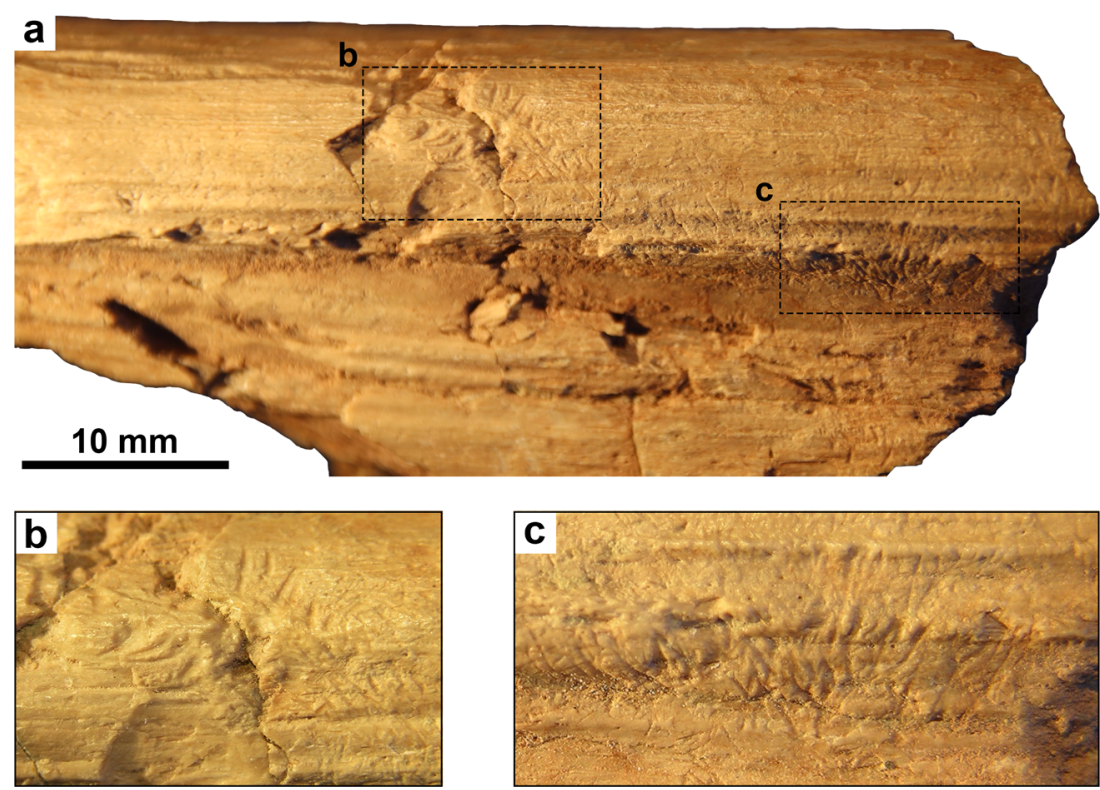
mammalian teeth recovered from Liuhuanggou mostly comprise molars and premolars that range in size from 0.5 to $1.5 \mathrm{~mm}$ (Martin et al. 2010). So far, only one incisor belonging to Sineleutherus uyguricus is known that has a cusp width of $200 \mu \mathrm{m}$ and thus matches the size of the larger bite marks very well (Fig. 2b). For the other four taxa from this locality, unfortunately, incisors are unknown, but their estimated size lies well within the range expected from the traces. Moreover, the traces here described show all the characteristics of feeding traces ascribed to mammals from the Late Cretaceous (Longrich and Ryan 2010; de Valais et al. 2012; Gianechini and de Valais 2015; Augustin et al. 2019).

Feeding traces by extant insectivorous mammals described in the catalogue of vertebrate taphonomic identifications by Fernández-Jalvo and Andrews (2016: Figs. A.175-186) are almost identical to the ones described here, lending further support to the interpretation of mammals as trace-makers. Interestingly, the bite marks of insectivorous mammals more closely resemble the traces from Liuhuanggou than those of rodents (Andrews 1990: Fig. 1.3E-F; Fernández-Jalvo and Andrews 2016: Figs. A.187-190). This is expected because of the similarity of the dentition pattern and the reconstructed diet between extant insectivorous mammals and the mammals described from Liuhuanggou (Pfretzschner et al. 2005). Therefore, we contend that the feeding traces can be confidently assigned to mammals based on the small size of the traces and their characteristic, paired arrangement with an opposing pair of bite marks preserved on the opposite side of ridges or protuberances.

Although the traces described herein are overall similar to bioerosional traces of insects, a thorough comparison with extant insectivore bite marks and accounts from the fossil record clearly indicates a mammalian origin of the traces. In general, the interpretation of trace fossils, especially bioerosional traces, is often contentious and a matter of debate. However, we are confident that the most likely explanation of the bioerosional traces presented in this study is feeding activity by mammals based on the typical arrangement in opposed pairs of some of the traces.

Due to the extreme size discrepancy of predator and prey, the bite marks clearly represent scavenging behaviour. Scavenging behaviour is expected in early mammals because of their moderate dental complexity that allowed a generalized diet. Additionally, animal tissue provides a source for proteins, lipids and minerals that are otherwise hard to obtain for such small animals with an estimated adult size of less than $100 \mathrm{~g}$. Since the feeding traces are only superficially preserved on the bone surface (Fig. 2b, c), they most likely were inflicted unintentionally during feeding. The arrangement of the bite marks along small ridges and the "gnawed" appearance of the bone surface, points to selective feeding on the remaining soft tissues of the dinosaur carcass that were still attached to the bones.

The mammalian bite marks described here represent the oldest direct evidence for a carnivorous diet in early mammals. They also represent the oldest record of scavenging behaviour.
Our findings expand the known range of the early mammalian feeding repertoire significantly and shed light on the palaeobiology and palaeoecology of early mammals, a field that has been poorly known for a long time. Until now, there was a significant gap between the earliest known mammals with a generalized heterodont dentition from the Late Triassic (220 Ma) and the oldest feeding traces from the Late Cretaceous (100 Ma). This study considerably reduces this gap.

Acknowledgements We would like to thank the Geological Survey No. 1 of Xinjiang, led by Prof. Zuo Xue-Yi, and the Museum and Research Centre of Palaeontology and Stratigraphy at the Jilin University, led by Prof. Sun Ge. We are grateful to three anonymous reviewers for their helpful suggestions, which improved our manuscript considerably. Handling editor Aurora Grandal D'Anglade and editor Paula Roig Boixeda are thanked for their assistance during the publication process.

Authors' contributions F.J.A. and A.T.M. designed the study; A.T.M., M.W.M. and H.-U.P. collected the specimen; F.J.A. and A.T.M. wrote the paper; M.W.M., J.K.H. and H.-U.P. commented on the manuscript and discussed the results.

Funding Information Open Access funding provided by Projekt DEAL.

Availability of data and material The specimen is currently housed at the Palaeontological Collection of the University of Tübingen and will eventually be transferred to a Chinese public collection.

\section{Compliance with ethical standards}

Conflict of interest The authors declare that they have no conflict of interest.

Open Access This article is licensed under a Creative Commons Attribution 4.0 International License, which permits use, sharing, adaptation, distribution and reproduction in any medium or format, as long as you give appropriate credit to the original author(s) and the source, provide a link to the Creative Commons licence, and indicate if changes were made. The images or other third party material in this article are included in the article's Creative Commons licence, unless indicated otherwise in a credit line to the material. If material is not included in the article's Creative Commons licence and your intended use is not permitted by statutory regulation or exceeds the permitted use, you will need to obtain permission directly from the copyright holder. To view a copy of this licence, visit http://creativecommons.org/licenses/by/4.0/.

\section{References}

Andrews P (1990) Owls, caves and fossils. University of Chicago Press, Chicago

Ashraf AR, Sun Y, Sun G, Uhl D, Mosbrugger V, Li J, Herrmann M (2010) Triassic and Jurassic palaeoclimate development in the Junggar Basin, Xinjiang, Northwest China — a review and additional lithological data. Palaeobiodiversity Palaeoenvironments 90:187201. https://doi.org/10.1007/s12549-010-0034-0

Augustin FJ, Matzke AT, Csiki-Sava Z, Pfretzschner H-U (2019) Bioerosion on vertebrate remains from the upper cretaceous of the Hațeg Basin, Romania and its taphonomic implications. Palaeogeogr Palaeoclimatol Palaeoecol 534:109318. https://doi. org/10.1016/j.palaeo.2019.109318 
Augustin FJ, Matzke AT, Maisch MW, Pfretzschner H-U (in press) First evidence of an ankylosaur (Dinosauria, Ornithischia) from the Jurassic Qigu Formation (Junggar Basin, NW China) and the early fossil record of Ankylosauria. Geobios. https://doi.org/10.1016/j. geobios.2020.06.005

Backwell LR, Parkinson AH, Roberts EM, d'Errico F, Huchet JB (2012) Criteria for identifying bone modification by termites in the fossil record. Palaeogeogr Palaeoclimatol Palaeoecol 337-338:72-87. https://doi.org/10.1016/j.palaeo.2012.03.032

Behrensmeyer AK, Gordon KD, Yanagi GT (1986) Trampling as a cause of bone surface damage and pseudo-cutmarks. Nature 319:768-771. https://doi.org/10.1038/319768a0

Britt BB, Scheetz RD, Dangerfield A (2008) A suite of dermestid beetle traces on dinosaur bone from the Upper Jurassic Morrison Formation, Wyoming, USA. Ichnos 15:59-71. https://doi.org/10. 1080/10420940701193284

de Valais S, Apesteguía S, Garrido AC (2012) Cretaceous small scavengers: feeding traces in tetrapod bones from Patagonia, Argentina. PLoS One 7:e29841. https://doi.org/10.1371/journal.pone.0029841

Eberth DA, Brinkman DB, Chen P, Yuan F-T, Wu S-Z, Li G, Cheng X-S (2001) Sequence stratigraphy, paleoclimate patterns, and vertebrate fossil preservation in Jurassic-cretaceous strata of the Junggar Basin, Xinjiang Autonomous Region, People's Republic of China. Can J Earth Sci 38:1627-1644. https://doi.org/10.1139/cjes-38-12-1627

Fang Y, Wu C, Guo Z, Hou K, Dong L, Wang L, Li L (2015) Provenance of the southern Junggar Basin in the Jurassic: evidence from detrital zircon geochronology and depositional environments. Sediment Geol 315:47-63. https://doi.org/10.1016/j.sedgeo.2014.10.014

Fang Y, Wu C, Wang Y, Wang L, Guo Z, Hu H (2016) Stratigraphic and sedimentary characteristics of the Upper Jurassic-Lower Cretaceous strata in the Junggar Basin, Central Asia: tectonic and climate implications. J Asian Earth Sci 129:294-308. https://doi.org/10.1016/j. jseaes.2016.09.001

Fejfar O, Kaiser TM (2005) Insect bone-modification and paleoecology of Oligocene mammal-bearing sites in the Doupov Mountains, northwestern Bohemia. Palaeontol Electron 8:1-11

Fernández-Jalvo Y, Andrews P (2016) Atlas of vertebrate taphonomic identifications: 1001+ images of fossil and recent mammal bone modification. Springer, Dordrecht Heidelberg New York London, 359 pp.

Fiorillo AR (1991) Pattern and processes in bone modification. Anthropologie 29:157-161

Gianechini FA, de Valais S (2015) Bioerosion trace fossils on bones of the Cretaceous South American theropod Buitreraptor gonzalezorum Makovicky, Apesteguía and Agnolín, 2005 (Deinonychosauria). Hist Biol 28:533-549. https://doi.org/10.1080/08912963.2014.991726

Hu Y, Meng J, Wang Y, Li C (2005) Large Mesozoic mammals fed on young dinosaurs. Nature 433:149-152. https://doi.org/10.1038/ nature 03102

Lee MSY, Beck RMD (2015) Mammalian evolution: a Jurassic spark. Curr Biol 25:R759-R761. https://doi.org/10.1016/j.cub.2015.07.008

Li S-L, Yu X-H, Tan C-P, Steel R (2014) Jurassic sedimentary evolution of southern Junggar Basin: implication for palaeoclimate changes in northern Xinjiang Uygur Autonomous Region, China. J Palaeogeogr 3:17. https://doi.org/10.3724/SP.J.1261.2014.00049

Longrich NR, Ryan MJ (2010) Mammalian tooth marks on the bones of dinosaurs and other Late Cretaceous vertebrates. Palaeontology 53: 703-709. https://doi.org/10.1111/j.1475-4983.2010.00957.x

Luo Z-X (2007) Transformation and diversification in early mammal evolution. Nature 450:1011-1019. https://doi.org/10.1038/ nature 06277

Maisch MW, Matzke AT (2003) Theropods from the Middle Jurassic Toutunhe Formation of the Southern Junggar Basin, NW China. Paläontol Z 77:281-292

Maisch MW, Matzke AT (2005) Temnospondyl amphibians from the Jurassic of the southern Junggar Basin (NW China). Paläontol Z 79:285-301
Maisch MW, Matzke AT (2014) The turtle Xinjiangchelys radiplicatoides BRINKMAN et al., 2013 (Reptilia: Testudines) from the Lower Qigu Formation (Upper Jurassic) of Liuhuanggou, Xinjiang, People's Republic of China. Palaeodiversity 7:133-147

Maisch MW, Matzke AT (2017) A large pterodactyloid pterosaur from the Upper Jurassic of Liuhuanggou, Xinjiang, People's Republic of China. N Jb Geol Paläont (Abh) 284:207-214. https://doi.org/10. 1127/njgpa/2017/0658

Maisch MW, Matzke AT, Pfretzschner H-U, Sun G, Stöhr H, Grossmann F (2003) Fossil vertebrates from the Middle and Upper Jurassic of the Southern Junggar Basin (NW China) - results of the SinoGerman Expeditions 1999-2000. Neues Jahrbuch Geol Paläontol Monatsh 5:297-313

Maisch MW, Matzke AT, Sun G, Pfretzschner H-U, Stöhr H, Grossmann F (2004a) Fossil Vertebrates of the Southern Junggar Basin - New Results of the Sino-German Expeditions 1999-2002. Proceedings of Sino-German Cooperation Symposium on Paleontology, Geological Evolution and Environmental Changes of Xinjiang, China 15-34

Maisch MW, Matzke AT, Sun G (2004b) A relict trematosauroid (Amphibia: Temnospondyli) from the Middle Jurassic of the Junggar Basin (NW China). Naturwissenschaften 91:589-593. https://doi.org/10.1007/s00114-004-0569-x

Maisch MW, Matzke AT, Grossmann F, Stöhr H, Pfretzschner H-U (2005) The first haramiyoid mammal from Asia. Naturwissenschaften 92:40-44. https://doi.org/10.1007/s00114004-0584-y

Martin T, Averianov AO, Pfretzschner H-U (2010) Mammals from the Late Jurassic Qigu Formation in the Southern Junggar Basin, Xinjiang, Northwest China. Palaeobiodiversity Palaeoenvironments 90:295-319. https://doi.org/10.1007/s12549010-0030-4

Olsen SL, Shipman P (1988) Surface modification on bone: trampling versus butchery. J Archaeol Sci 15:535-553. https://doi.org/10. 1016/0305-4403(88)90081-7

Pfretzschner H-U, Martin T, Maisch MW, Matzke AT, Sun G (2005) A new docodont mammal from the Late Jurassic of the Junggar Basin in Northwest China. Acta Palaeontol Pol 50:799-808

Pomi LH, Tonni EP (2011) Termite traces on bones from the Late Pleistocene of Argentina. Ichnos 18:166-171. https://doi.org/10. 1080/10420940.2011.601374

Richter A, Wings O, Pfretzschner H-U, Martin T (2010) Late Jurassic Squamata and possible Choristodera from the Junggar Basin, Xinjiang, Northwest China. Palaeobiodiversity Palaeoenvironments 90:275-282. https://doi.org/10.1007/s12549010-0037-x

Schellhorn R, Schwarz-Wings D, Maisch MW, Wings O (2009) Late Jurassic Sunosuchus (Crocodylomorpha, Neosuchia) from the Qigu Formation in the Junggar Basin (Xinjiang, China). Fossil Record 12:59-69. https://doi.org/10.1002/mmng.200800010

Tong HW, Zhang S, Chen F, Li Q (2008) Rongements sélectifs des os par les porcs-épics et autres rongeurs : cas de la grotte Tianyuan, un site avec des restes humains fossiles récemment découvert près de Zhoukoudian (Choukoutien). L'Anthropologie 112:353-369. https://doi.org/10.1016/j.anthro.2008.04.006

Wings O, Pfretzschner H-U, Maisch MW (2007) The first evidence of a stegosaur (Dinosauria, Ornithischia) from the Jurassic of Xinjiang/ China. N Jb Geol Paläont (Abh) 243:113-118. https://doi.org/10. 1127/0077-7749/2007/0243-0113

Publisher's note Springer Nature remains neutral with regard to jurisdictional claims in published maps and institutional affiliations. 